\title{
POSSIBILITIES OF PREVENTION AND REDUCTION OF THREATS AFFECTING THE SAFETY AND FLUIDITY OF LAND TRANSPORT
}

\author{
Josef Reitšpís ${ }^{1}$, Martin Mašlan²
}

\begin{abstract}
Ensuring mobility and the necessary volume of transportation is one of the basic conditions for the functioning of the economy. The potential threat to existing transport systems is therefore an area that needs increased attention. The complexity of modern transportation is due to its increasing frequency, the expansion of transport routes, as well as the increase in the number of actors involved in their implementation, which places ever greater demands on their mutual coordination. It is necessary to constantly monitor the progress of transportation, to identify and assess the risks that may affect them. Insufficient attention to this issue can lead to time and material losses, in the worst case, the death of their participants, or to the high financial costs required to rebuild the disrupted system. Transport is an open system in which more and more people are working, whether transported or involved in its organization, which increases the possibility of their failure and facilitates the possibility of attack. Strict application of risk management, assessment and, if necessary, implementation of necessary measures can lead to protection of high-value assets. At present, we already commonly encounter concepts such as the intelligent transport route or the autonomous means of transport. All these circumstances, as well as the importance of transport, which we could compare to blood circulation of the state's economy, make it a possible target for various types of attacks. Cyber threats and attacks are becoming more and more relevant today. Such an attack is characterized by a relatively low level of threat to the attacker himself and a possible high level of damage if it is successful.
\end{abstract}

Key words: land transport, road transport, rail transport, security threats, logistics, cyber attack, risk management.

JEL Classification: L92, R41, R42, J28, K24

\section{Introduction}

The development of the global economy is largely dependent on the free movement of people, goods and information. We are witnessing a globalized world, but this does not mean global security. World globalization also directly affects transportation, which is rapidly growing in importance and intensity. Both the number of transported persons and the volumes of materials are increasing, the transport routes that can lead through or over risk areas are being extended. A characteristic feature is the fact that transport infrastructure is developing more slowly on a global scale than the requirements it has to meet. The transport system is currently exposed to security threats, both to the known ones, which are constantly taking on modified forms, as well as to many new ones, which are so far only intuitively suspected, or

\footnotetext{
Corresponding author:

${ }^{1}$ University of Security Management in Košice, Slovakia.

E-mail: josef.reitspis@vsbm.sk

ORCID: https://orcid.org/0000-0003-4248-5758

${ }^{2}$ University of Security Management in Košice, Slovakia.

E-mail: martin.maslan@vsbm.sk

ORCID: https://orcid.org/0000-0003-1913-655X
}

even unknown at all. Certain types of transportation have their own specifics; their object may be hazardous substances and materials that pose a threat both to the participants of transportation and to the civilian population located along the transportation routes, or to the general safety of the state. The combination of various factors accumulates safety risks affecting transport and their possible consequences. Continuous identification of these risks, their analysis using appropriate methods that take into account the nature of the system under analysis, subsequent analysis and evaluation of the identified risks, the development of necessary measures, as well as the inclusion of the acquired knowledge in the practical and theoretical training of transport participants is a necessary condition for safe and uninterrupted operation of transport. It must be stated that the level of vulnerability of the system is still increasing. 
An important condition for the safe and uninterrupted operation of transport is the implementation of corrective and preventive measures developed on the basis of the identification and assessment of risks affecting the transport system. Despite the everincreasing attention paid to the management of safety risks arising from transport, more than 1.3 million people die in road accidents worldwide each year. Depending on the country, the implementation of the necessary measures may depend on their funding possibilities, but also on conflicts over the provision of passenger security, taking into account the privacy of their guaranteed rights. The flow of transport is largely influenced by the level of protection of the individual assets that are part of the existing transportation system.

The present time is a period of increasing importance of the use of information technology, which leads to attempts to abuse it, aimed at the economic, military and political weakening of the enemy. For the operation of transports it is important to maintain the ability to function in the event of unauthorized access to the information system, penetration of misinformation, damage to existing databases, which can lead to its partial or complete disruption. The protection of information systems includes elements that increase their resilience, as well as the possibility of transport operation in the event of their failure. Transportation requires the interconnection of a large number of information systems, which increases the possibility of putting them at risk. In order to increase system resilience, it is constantly necessary to upgrade existing and add new security features to hardware and software. The problem is the rapid development of information technology and cyber threats, which is incompatible with the service life of vehicles. When purchasing vehicles, it is necessary to consider not only price, quality, functionality, but also the integration of modern elements of active and passive security.

\section{Safety aspects affecting the transport system}

If we understand transport as an organized system with three interacting basic elements, which are the transport route, means of transportation and participants (active or passive), then we can argue that security threats can refer to one of the elements and their possible combinations. The consequences of a flow restriction or supply disruption can affect both local and global security, and can lead to negative impacts on the health and lives of people involved in the supply chain, as well as people who are not involved in the system at all. Other consequences are various forms of damage to property, which may be the transport infrastructure, the transported material, the means of transport, or property that has no direct connection with the transport itself.
Transport and its security system are constantly evolving, and the individual elements are characterized by different paces of such development. The advancement of vehicles, in which new elements of passive and active safety are constantly being applied, is most noticeable. The vehicle and the active participant - the driver act interactively, the active safety features applied contribute to the reduction or elimination of safety risks from the driver, which may gradually lead to its complete replacement and the production of autonomous vehicles. The road-vehicle interaction has been the subject of extensive research in various countries around the world for many years. We are increasingly confronted with the terms 'smart road', 'smart highway' or 'intelligent transport system', which will become part of real life in the future.

These facts could give the impression that the vulnerability of transport systems is constantly increasing due to the technical improvement of their elements. This is just one of the prerequisites for the safe operation of the system. The second is the constant monitoring of the security risks and threats to which this system is exposed. In general, we can divide security threats affecting traffic into 3 groups:

1. Objective (existing without human intervention, thus arising independently of human action). We advise you on these:

a) Technical failures, technological deficiencies and accidents on the road or means of transport;

b) Natural disasters - seismic, volcanic, climatic.

2. Subjective (caused by transport participants, whether active or passive, or by other human actions):

a) Subconscious-unconscious action e.g. under the influence of health problems;

b) Conscious action - intentional or unintentional (eg neglect, arrogance, aggression, influence of alcohol).

3. External attacks on the transport system:

a) Individual and/or organized crime;

b) Terrorism - individual and/or organized, for example, attacks using "CBRNE" threats, i.e. "chemical, biological, radioactive, nuclear and explosive". Cyber threats and the use of vehicles as weapons are also increasingly mentioned in this context.

The degree of action of individual threats can lead to extraordinary events, which have different probabilities of occurrence, as well as the severity of consequences. Therefore, it is essential to constantly monitor the security aspects of traffic by analyzing and assessing existing security risks. Every extraordinary event requires a thorough analysis, which examines the causes, course and consequences of its occurrence. Based on the knowledge gained in this way, it is possible to propose the necessary measures. The primary task of corrective measures is to restore the functionality of the transport system. In contrast, preventive measures seek to reduce the existing risk to an acceptable level, which should protect the system from further emergencies. 
Therefore, the safety of transport and its individual components depends to a large extent on preparing the system for possible risk situations and the occurrence of emergency events. This activity is the subject of risk management, i.e., management that prepares the system for action in emergency and crisis situations.

\subsection{The importance of logistics for the functioning of sectors of the national economy}

The basis of logistics can be derived from the need to address logical procedures (processes) related to the satisfaction of basic human needs, such as satiety or clothing. According to Junemann, "Logistics - the scientific science of planning, managing, and controlling the flow of materials, people, energies, and information in systems" (Junemann, 1989). The European Logistics Association defines logistics as the organization, planning, management and performance of flows starting with development and purchasing, ending with production and distribution according to the order of the final customer so that all market requirements are met at minimum cost and minimum capital expenditure.

Since its inception, logistics activities have undergone a gradual development, which is a necessary prerequisite for meeting the ever-changing requirements. They are reoriented from the market of the seller to the market of the buyer, while the delivery time is reduced and the level of provided services increases. The products manufactured are characterized by higher production quality, as well as a shorter life cycle and a growing assortment while constantly striving to reduce inventories.

The main determining factor in the development of this activity was the transition from manual administration and data processing to their electronic form and the introduction of systems that allow for comprehensive monitoring of logistics processes in real time. Nowadays, logistics activity is an integrating element of both individual internal components of the system and the connection of this system with the environment. The main prerequisite for this integration is a functional information system, which in real time:

- provides information on material flows and current conditions in individual warehouses;

- updates the production status;

- indicates the need to purchase inventory, allows distribution planning;

- provides information on existing and potential customers and suppliers;

- informs about the status of materials at suppliers;

- monitors the ordering process;

- monitors the volume, composition and price level of ordered and delivered products;
- shows the financial flows and payment discipline of the participants;

- monitors the quality of ordered and delivered materials.

Thus, properly selected and implemented information system can largely ensure the mutual replacement of information and material flows, as well as reduce productivity and logistics costs.

The reason for the functioning of the logistics system defined in this way is the ever-increasing requirements for the volume of transport of people and materials. Such shipments can serve as inputs to production processes, transfers within existing productions and intermediate warehouses, a means of meeting the needs of end customers through the delivery of required products and services. At a time of globalization, these transports are characterized by increasing risk factors, such as internationalization, an increase in the length of transport routes and transportation volumes, and an increase in the number of people needed to organize them. Therefore, to ensure the safe functioning of logistics and transportation systems, constant attention must be paid to existing and emerging risks.

\subsection{Land transport and its operation in the Slovak Republic}

In the conditions of the Slovak Republic, road transport is mostly used for these purposes. The main advantages of this type of transport include its speed, reliability, flexibility, possibility of direct sale of transported goods and its independence from other modes of transport, diversity of the offered fleet of vehicles. Road transport is mainly used for short- and medium-distance transportation. An important factor favoring this mode of transport is the large number of roads, which is due to the accessibility of the final destination, the lack of the need to combine with other modes of transport, and the lower cost of repairing infrastructure in case of damage.

The second most used mode of transport is rail, which is limited by transport routes, the need for access roads, lower speed and higher cost. Its advantage is the low environmental impact and minimal impact of weather conditions. Although this mode of transport allows unrestricted movement of materials and people, it is subject to the above-mentioned limitations. This transport works most effectively for direct transport from train to train. In other cases, it must be combined with road transport for efficient delivery. The speed of transport is greatly influenced by the number of consignors and consignees within one train. The fastest transport is performed by a direct integrated train, i.e. by a train which transports consignments from one transmitting station from one consignor to one receiving station (siding) for one consignee. The disadvantage is the very problematic transport of oversized materials 
and the time that this method of transportation requires when delivering materials from multiple senders, from multiple stations to multiple recipients.

In the conditions of the Slovak Republic, domestic water transport is of only marginal importance due to the insufficient length of navigable watercourses. In general, it is the most cost-effective mode of transportation, suitable for transporting large volumes of materials over long distances. The disadvantages are the speed of transportation, fluctuations in the condition of watercourses and weather conditions. The technical equipment of existing ports is also a limiting factor. It is also necessary to combine this transport with other modes of transportation and distribution i.e. rail and road transport. Since the Slovak Republic is a landlocked country, sea transport is only minimally used in the conditions of the Slovak Republic. However, in a global sense, this mode of transport is a means of strategic mobility.

According to existing estimates, the importance of road transport will continue to grow, to the detriment of rail and water transport. The estimates of the European Commission concerning the performance of individual types of transport for the years 2018-2030 in the conditions of the Slovak Republic are shown in the Figure 1.

Combined transport (CT) is a transport and handling system ensuring the transport of goods in one and the same cost unit from the sender to the recipient as an unbroken chain. In essence, it is not a separate mode of transport, but an efficient use of interconnected modes of transport (rail, road, air and waterborne), which, due to their comparative and systemic advantages, can reliably meet transport requirements. Intermodality is a transport system in which two or more types of transport are used for the continuous transport of the same load unit within the supply chain.

In the conditions of the Slovak Republic a combination of road and rail transport or cooperation of these modes of transport with water and sea transport is used, to a lesser extent air transport is also involved in such transportation. The basic condition for quality performance of transport logistics tasks is mobility, i.e. the possibility to move the necessary volume of materials or people quickly, either by means of own transport capacities or by renting transport services offered from outside. In ensuring the necessary level of mobility, we always take into account factors that may negatively affect it.

\section{Characteristics of safety risks affecting fluidity of land transport}

The purpose of identifying risk factors is to create a list of events (risk catalog) that could lead to an undesirable disruption of current processes. At this stage it is necessary to identify as many risks as possible, which will later be analyzed and evaluated. When identifying risk factors, both external and internal environmental influences must be considered. Although individual land transports have their own specifics (weather, transport routes), they also show common elements within which individual risk factors act. The basic prerequisite for effective risk management is its knowledge which enable us to provide following activities:

Risk analysis: it is the process of assessing the causes and sources of risks, their positive and negative

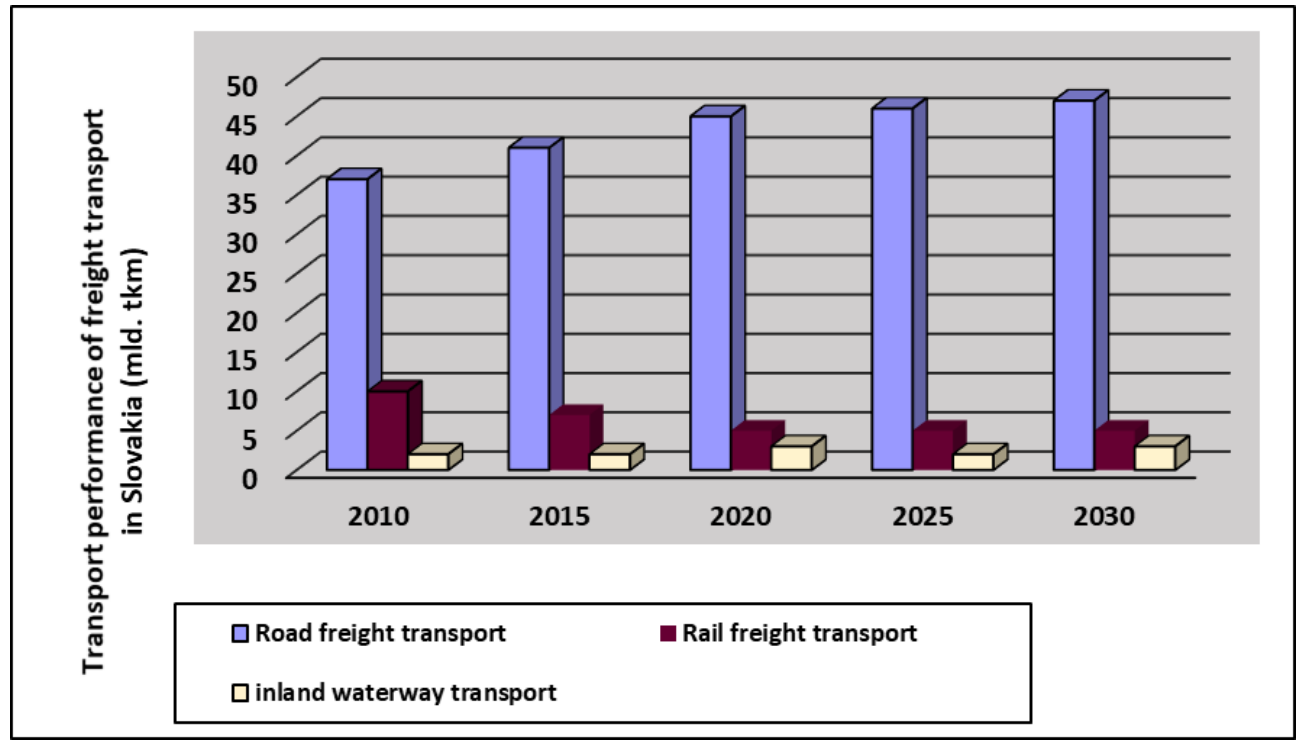

Figure 1. Prediction of the development of transport performance in freight transport in Slovakia until 2030

Source: European Energy and Transport, Trends to 2030, European Commission 
impacts, the severity of possible impacts and then determining the likelihood that these impacts may occur. The choice of risk analysis method depends on the nature of the system under investigation itself, on the availability and complexity of the input information - this must be reliable, relevant and must carry the required data, from the stage of development of the research. Identifying of risk factors create a list of events that could cause undesirable disruption to ongoing processes. At this stage, we define all the risks that will be subsequently analyzed and evaluated. When identifying risk factors, we can use analythiclal methods as Check list (CA), Preliminary Hazard Analysis (PHA).

This analysis serves as a basis for further analyzes such as Ishikawa diagram, ETA or FTA as a risk modelling methods or FMEA as a method for basic analysis of the system. Methods for risk modelling enable to create teh scenarios in the course of risk event, based on cause-and-effect diagrams displayed the analyzed problem in a simple form based on its causes.

The most commonly used methods for basic system analysis is FMEA (Failure Mode and Effect Analysis). Analysis of the causes of failures and their consequences, the task of which is to select significant risks affecting the system under investigation. The result of the analysis is a clear tabular and graphical representation of both acceptable and unacceptable risks. When designing measures for individual risks, it is always necessary to take into account how the individual components contributed to the total amount of the risk number. If there is a possibility of a high severity of consequences but a very low probability of an event, it may not be necessary to take precautionary measures.

Risk evaluation: a complex process in which we determine the magnitude of risk in terms of the extent of damage and loss that a given crisis event may cause and the likelihood that such an event will occur, we compare the degree of risk to existing standards, tolerance limits or other predetermined criteria. Based on the degree of risk, we determine the order of risks in terms of their significance, taking into account the impact of the probability of occurrence and possible consequences. We then compare the individual risks with the level of acceptability and decide which risks we will consider further.

Risk treatment and reduction: is a diverse process, which depends on the nature of the risk itself, the degree of probability of a crisis phenomenon that may cause the risk and the expected negative consequences. Thus, risk reduction can be achieved, for example, through crisis policy, risk diversification (insurance), but also by creating reserves or optimizing processes.

Familiarization of the persons concerned with the residual risks: instruction of competent staff about the risk factors that exist in the individual processes and activities.
Ongoing monitoring of the level of risks and the implementation and effectiveness of the measures in place. In this process, the existence of feedback and the continuous incorporation of control findings into the system is essential.

Among the security threats which affect land transport and currently need to be given increased attention, we can include:

- Ensuring the operability of the system even in the event of a cyber threat. Focus future research on an integrated approach to ensuring cyber resilience in land transport. The need to ensure a degree of flexibility of IT systems against possible cyber attacks. Ensuring the operation of transport systems even in the event of an IT failure.

Adaptation of existing IT systems to emerging cyber risks - analysis of threats and deficiencies, measures to eliminate emerging security gaps.

- Timely and effective threat detection. An integrated approach to the timely and effective detection of threats in land transport.

- Safety problems of railways as open systems. Focusing research on an integrated approach to railway safety and public transport - detection, crisis management and human resources training.

- Balancing security requirements and passenger privacy. Privacy and security are often threatened, but also in competing areas. Focus on tools that take privacy and fundamental human rights into account when implementing security measures.

- Security awareness of staff and customers. Focused on training and educational programs for security personnel and measures for seamless communication with passengers.

- Safety as part of system design. The goal is to offer solutions in which security elements will be incorporated into the ground transportation hardware. This eliminates the additional costs associated with the purchase of additional security features. Security should be part of the ICT (information and communication technology) design. A comprehensive approach to transport ICT security design. Increased security risks require the design of ICT systems with directly embedded security features.

- Secure communication links for traffic management systems. Risk assessment and safety protocols for traffic management systems. The number of interconnected control systems as well as systems enabling self-monitoring is constantly growing (see also autonomous vehicles)

- Protection of autonomous vehicles against cyber attacks. Protection of autonomous vehicles through the joint development and harmonization of cyber vehicle architecture, reliable communication systems and more efficient knowledge exchange.

Overall transportation safety is always a reciprocal interaction of its individual components, which are 
route-means of transportation and human factors. Lack of attention to the security risks posed by these components can mean an overall threat to the mobility necessary for the functioning of society, as well as undesirable synergies that can be achieved at the expense of low costs and the anonymity of perpetrators at a low level of system security. A characteristic feature of the modern world is its globalization and increasing international tensions, factors that also lead to an increase in security risks and related threats affecting transportation systems.

\section{Conclusion}

The complexity of current transports is due to their growing frequency, extension of transport routes, as well as the growing number of entities that participate in their implementation, which places ever-increasing demands on their mutual coordination. Increasingly, external services are being rented out, either by transport customers or their providers. Outsourcingusing of external capacities represents advantages related to specialization, speed of deliveries, or their actual implementation in case of insufficient internal capacity, or quality of provided services. However, this always means the entry of an external element into the system, whose staff, IT systems and activities cannot be controlled and managed as efficiently as existing internal resources.

A prerequisite for the functioning of the transport security system is the continuous innovation of existing technical equipment and technologies, which should ensure their functionality and ability to respond to existing and anticipated security risks and threats that may occur in this system. The level of use of established technologies always depends on the knowledge, motivation and working conditions of the staff -internal or external who work with existing technologies. Within transport, we can define the following areas of use of security technologies, systems and related activities:

- Access control;

- Security of transport assets and cargo;

- Cyber protection;

- Safety of employees, visitors, passengers;

- Loss prevention;

- Perimeter protection of space and buildings;

- Place of transaction.

Nowadays, we already often encounter such concepts as the intelligent transportation route or autonomous means of transportation. All these circumstances, as well as the importance of transportation, which we could compare to the circulation of the state's economy, make it a possible target for various types of attacks. Cyber threats and attacks are becoming more and more relevant today. Such an attack is characterized by a relatively low level of threat to the attacker himself and possible high damage in its successful implementation. An increasingly important place in management activities, therefore, occupies risk management. It is a continuous process that is a means of effectively identifying and assessing risks, in case there is a need to design and implement the necessary measures. The implementation of these measures is often associated with the need to spend certain funds. The need to secure these funds means an increase in the total cost of running the system, but overall they represent only a certain percentage of the total value of the asset to be protected by these measures.

\section{References:}

Soušek, R. (2010). Doprava a krízový managament. Pardubice: Institut Jana Pernera, 260 s. ISBN 978-80-86530-64-2

Mesároš, M., Kiss, I., \& Majerník, L'. (2008). Logistika, VŠBM, Košice, 108 s. ISBN 978-80-89282-17-3

Kortschak, B. H. (1994). Úvod do logistiky: Co je logistika? Praha: Babtext, 176 s. ISBN 80-85816-06-7

Buzalka, J. (2012). Teória bezpečnostných rizík. Bratislava: Akadémia PZ, 168 s. ISBN 978-80-8054-547-5

Smejkal, V., \& Rais, K. (2006). Rízení rizik ve firmách a jiných organizacích. Praha: Grada publishing, a.s., 300 s. ISBN 80-247-1667-4

Reitšpís, J., Bartlová, I., \& Hofreiter, L. (2004). Manažérstvo bezpečnostných rizík. Žilina: Edis - vydavatel'stvo Žilinskej university, 296 s. ISBN 80-8070-328-0

Přibil, P., Janota, A., \& Spalek, J. (2008). Analýza a řízení rizik v dopravě. Praha: BEN-technická literature, 526 s. ISBN 978-80-7300-2140-0

Straka, M. (2013). Logistika distribúcie, EPOS, 399 s. ISBN: 978-80-56200-15-5

Tichý, M. (2006). Ovládání rizika:analýza a management. Praha: C.H.Beck, 396 s. ISBN 80-7179-415-5

Paleček, M. (2006). Prevence rizik. Praha: VŠE. ISBN 80-245-1117-7

Hofreiter, L. (2004). Bezpečnost', bezpečnostné riziká a ohrozenia. Žilina: Edis - vydavatel'stvo Žilinskej university, 146 s. ISBN 80-8070-181-4

Kuracina, R., \& Ferjenčík, M. (2006). Nástroje pre oceňovanie rizika a vyšetrovanie havárií. Recenzovaný zborník. ISBN 80-8073-649-9

Zborníky z vedeckých konferencií Riešenie krízových situácií v špecifickom prostredí, FŠI ŽU, Žilina, 1996-2005. STN EN ISO 31000:2011:Manažérstvo rizika. 